\title{
FORMULASI DAN UJI STABILITAS FISIK SEDIAAN EMULSI MINYAK IKAN LEMURU (Sardinella lemuru)
}

\author{
Patihul Husni ${ }^{1}$, Yasarah Hisprastin ${ }^{1}$, Melinda Januarti ${ }^{2}$ \\ ${ }^{1}$ Fakultas Farmasi, Universitas Padjadjaran, Jatinangor \\ ${ }^{2}$ Klinik Padjadjaran, Jatinangor \\ Email : patihul.husni@unpad.ac.id
}

\begin{abstract}
Lemuru fish (Sardinella lemuru), a small type of pelagic fish, is often found in Indonesia. Lemuru fish oil contains high omega-3 which is benecficial for health. One effort that can be done to optimize the benefits of lemuru fish oil is formulated as an emulsion dosage form. The purpose of this study was to determine the formula and physical stability of the lemuru fish oil emulsion. The method in this study included preparation of emulsions with varian concentration of fish oil (F1: 5\%, F2: 10\%, and F3: 15\%) using natural emulgators (gummi arabicum) and physical stability tests carried out at two temperature variations, $25^{\circ} \mathrm{C}$ and $40^{\circ} \mathrm{C}$ for 30 days. Physical stability tests included organoleptic, homogeneity, emulsion type, viscosity, $\mathrm{pH}$, and the size of the average globule. The organoleptic test results showed that the three formulas showed phase separation at different time points at both the storage temperatures. The viscosity test results showed that the viscosity of the three formulas has decreased during the storage period. In the emulsion type test it was shown that all three formulas had an oil-in-water $(\mathrm{O} / \mathrm{W})$ emulsion type. The $\mathrm{pH}$ test results indicated fluctuations during the storage period. The average globul size test results showed that the F3 emulsion formula has a larger average globule size than F1 and F2. In conclusion, the most stable formula was F3 that containing $15 \%$ fish oil. F3 was stable for more than 21 days at $25^{\circ} \mathrm{C}$ and more than 14 days at $40^{\circ} \mathrm{C}$.
\end{abstract}

Key Words: Lemuru fish oil, emulsion, physical stability.

\section{PENDAHULUAN}

Indonesia merupakan negara kepulauan terbesar di dunia yang memiliki luas perairan sebesar $3.257 .483 \mathrm{~km}^{2}$. Luasnya laut Indonesia menandakan banyaknya jumlah dan variasi ikan yang ada di laut sehingga hasil perikanan melimpah. Data Kementerian Kelautan dan Perikanan tahun 2014 menyatakan bahwa produk olahan industri perikanan mencapai 5,37 juta ton pada tahun $2014 .^{1}$

Ikan lemuru (Sardinella lemuru) merupakan jenis ikan pelagis kecil yang banyak dijumpai di perairan Indonesia khususnya di perairan Selat Bali. Data penelitian Listiyani et al. $(2017)^{2}$ menyatakan bahwa pada tahun 2015 produksi ikan lemuru di Pelabuhan Perikanan Pantai Muncar mencapai lebih dari 10 juta ton. Ikan lemuru sebagian besar dimanfaatkan sebagai bahan baku untuk ikan kaleng, tepung ikan, dan minyak ikan. Ikan lemuru termasuk ikan dengan berlemak tinggi dengan kandungan minyak lemak yang tinggi serta bervariasi. Minyak ikan yang berkualitas adalah minyak ikan yang kaya akan asam lemak yang bermanfaat bagi kesehatan. Omega-3 merupakan salah satu asam lemak tak jenuh esensial dan dibutuhkan oleh tubuh. Berdasarkan penelitian Rubio-Rodriguez et al. $(2010)^{3}$ ikan_lemuru mengandung omega-3 tertinggi ketiga diantara ikan laut lainnya setelah mackerel dan salmon. Eikosapentanoat (EPA) dan 
dekoheksapentanoat (DHA) merupakan jenis omega-3 yang dominan terdapat pada minyak ikan. Omega-3 diketahui bermanfaat untuk mencegah penyakit jantung koroner, menurunkan kolesterol, dan meningkatkan kesehatan untuk otak dan mata. ${ }^{3}$

Kandungan asam lemak yang cukup tinggi pada ikan lemuru menjadikan minyak ikan lemuru mudah mengalami oksidasi dan pembusukan, baik karena aktivitas mikrobiologis maupun autolisis. Hal ini merupakan salah satu hambatan masyarakat dalam mengonsumsinya. Salah satu cara untuk mengatasinya adalah dengan memformulasikan minyak ikan lemuru menjadi sediaan emulsi. Emulsi merupakan suatu sistem sediaan heterogen yang terdiri atas dua larutan yang tidak menyatu dimana salah satu fase terdispersinya sebagai tetesan seragam di dalam fase lainnya. Hasil penelitian Haryati et al. $(2017)^{4}$ diketahui kandungan EPA dan DHA pada minyak ikan lemuru dapat dimanfaatkan dalam pembuatan emulsi.

Kajian mengenai stabilitas emulsi minyak ikan lemuru belum banyak dilakukan. Penelitian sebelumnya yang dilakukan oleh Permadi $(1999)^{5}$ yaitu pembuatan emulsi minyak ikan sardin dengan menggunakan lesitin dan tween sebagai pengemulsi dan carboxymethylcelulosa (CMC) sebagai penstabil menghasilkan tingkat kestabilan emulsi yang rendah yaitu selama 28 jam. Selanjutnya penelitian yang dilakukan Suseno et al. (2017) ${ }^{6}$ yaitu pembuatan emulsi minyak ikan lemuru menggunakan whey protein sebagai pengemulsi dan guar gum sebagai penstabil hanya memiliki kestabilan hingga hari ke-18 penyimpanan. Oleh karena itu penelitian ini perlu dilakukan untuk membuat sediaan emulsi dengan menggunakan emulgator yang sesuai sehingga diharapkan dapat meningkatkan stabilitas emulsi yang memiliki daya simpan lebih lama.

\section{METODE PENELITIAN}

\section{Alat dan bahan}

Alat yang digunakan dalam penelitian ini adalah alat-alat gelas laboratorium di Universitas Padjadjaran, mixer (STIRER $\mathrm{IKA}^{\circledR}$ ), homogenizer (WiseTis), timbangan analitik (Mettler Toledo), viskometer brookfield (DV-E), magnetic stirrer (Yellowline), climatic chamber (Irmeco), pH meter (Mettler Toledo), Particle Size Analyzer (Beckman Coulter), kaca arloji, mortar dan stamper. Bahan-bahan yang digunakan dalam penelitian ini yaitu minyak ikan lemuru (Sardinella lemuru) dari Kementerian Kelautan, gliserin (Brataco), gom arab (Brataco), xanthan gum (Brataco), BHT (Brataco), essence, natrium benzoat (Brataco), dan aqua destilata.

\section{Prosedur penelitian}

\section{Formula sediaan emulsi}

Sediaan emulsi minyak ikan lemuru dibuat dalam tiga formula (F1, F2 dan F3) yang mengandung konsentrasi minyak ikan lemuru yang berbeda. Komposisi ketiga formula tertera pada tabel 1 .

\section{Pembuatan sediaan emulsi}

Pembuatan sediaan emulsi minyak ikan lemuru dilakukan sesuai dengan metode penelitian Suseno et al. $(2017)^{6}$ dengan beberapa modifikasi. Pertama, bahan-bahan ditimbang sesuai dengan berat masingmasing. Gom arab sebagai emulgator ditambahkan dengan sejumlah aquadest didalam beaker glass lalu diaduk menggunakan mixer dengan selama 15 menit. Emulgator adalah fase air. Minyak ikan lemuru didalam beaker glass ditambahkan BHT dan 
dihomogenkan menggunakan homogenizer dengan kecepatan $30 \mathrm{rpm}$ selama 1 menit. Selanjutnya minyak sedikit demi sedikit ditambahkan ke dalam fase air dan diaduk menggunakan mixer selama 15 menit hingga terbentuk korpus emulsi. Xanthan gum dikembangkan menggunakan aquadest dan gliserin sampai mengental lalu dimasukkan ke dalam korpus emulsi dan dihomogenkan dengan kecepatan $50 \mathrm{rpm}$ selama 5 menit. Natrium benzoat ditambahkan kedalam emulsi dan diaduk menggunakan mixer. Pada akhirnya, ditambahkan sakarin dan essence secukupnya sambil diaduk hingga didapatkan rasa dan warna yang sesuai.

\section{Evaluasi stabilitas fisik sediaan emulsi}

Evaluasi stabilitas fisik sediaan emulsi dilakukan dalam dua kondisi suhu yaitu suhu $25^{\circ} \mathrm{C}$ (suhu kamar) dan suhu $40^{\circ} \mathrm{C}$ dengan cara menyimpan sediaan pada climatic chamber dengan suhu yang diatur $40^{\circ} \mathrm{C}$ dan kelembaban $75 \%$. Evaluasi tersebut dilakukan pada hari ke- $0,7,14,21$, dan 30 hari.
Uji organoleptis: pengamatan sediaan emulsi dilakukan dengan mengamati dari segi penampilan, rasa, aroma dan homogenitas dari sediaan uji (F1, F2, dan F3). ${ }^{7}$

Uji tipe emulsi: uji tipe emulsi dilakukan dengan menggunakan methylene blue yang dapat memberi warna biru pada emulsi tipe $\mathrm{O} / \mathrm{W}^{8}$

Uji viskositas: pengukuran viskositas sediaan dilakukan dengan menggunakan viskometer Brookfield. $^{6}$ Viskometer yang digunakan adalah Viskometer Brookfiled DV-E dengan spindle nomor 2 .

Uji $\mathrm{pH}$ : pengukuran $\mathrm{pH}$ dilakukan dengan menggunakan $\mathrm{pH}$ meter. Elektroda sebelumnya telah dikalibrasi. Kemudian elektroda dicelupkan ke dalam sediaan, $\mathrm{pH}$ yang muncul diamati dan dicatat. ${ }^{6}$ Kriteria nilai $\mathrm{pH}$ emulsi adalah $\mathrm{pH}$ oral $(5,5-7,5){ }^{9}$

Uji ukuran globul: diameter globul emulsi diukur menggunakan instrument Particle Size Analyzer. ${ }^{6}$ Kriteria ukuran globul sediaan emulsi berada pada rentang $0,1-100 \mu \mathrm{m} .^{10}$

Tabel 1. Formula emulsi (Suseno et al. (2017) ${ }^{6}$ yang dimodifikasi)

\begin{tabular}{cccc}
\hline \multirow{2}{*}{ Bahan } & \multicolumn{3}{c}{ Jumlah(\% b/v) } \\
\cline { 2 - 4 } & $\mathbf{F 1}$ & $\mathbf{F 2}$ & $\mathbf{F 3}$ \\
\hline Minyak ikan & 5 & 10 & 15 \\
Gliserolum & 4,5 & 4,5 & 4,5 \\
Gom Arab & 15 & 15 & 15 \\
Xanthan gum & 1 & 1 & 1 \\
BHT & 0,05 & 0,05 & 0,05 \\
Sakarin & 0,1 & 0,1 & 0,1 \\
Essence & 4 & 4 & 4 \\
Na. Benzoat & 0,1 & 0,1 & 0,1 \\
Aquadest ad & 100 & 100 & 100 \\
\hline
\end{tabular}

\section{HASIL DAN PEMBAHASAN}

Pembuatan minyak ikan lemuru menjadi sediaan emulsi dilakukan dengan tujuan untuk menghilangkan rasa berminyak dari minyak ikan lemuru agar menjadi produk yang lebih baik dengan mengurangi atau menutupi rasa berminyak tersebut. Tipe emulsi yang dipilih adalah tipe minyak dalam air $(\mathrm{O} / \mathrm{W})$ dikarenakan untuk sediaan oral, tipe emulsi ini dapat memberikan kenyamanan saat dikonsumsi.

Dalam pembuatan sediaan emulsi minyak ikan lemuru, emulgator yang digunakan adalah emulgator yang berasal dari 
alam yaitu gom arab. Gom arab merupakan koloid hidrofilik polisakarida yang dapat berfungsi sebagai emulgator. Koloid hidrofilik berperan sebagai emulgator dengan cara menyelubungi globul minyak dengan lapisan multilayer untuk mencegah globul-globul untuk bersatu kembali. Senyawa-senyawa koloid hidrofilik tersebut diadsorpsi pada antar muka minyak-air dan akhirnya terbentuk lapisan hidrofilik di sekitar globul sehingga setiap molekul terikat pada beberapa titik pada antar muka minyak-air. ${ }^{11,12}$ Sebagai emulgator, gom arab dapat digunakan pada konsentrasi 10 $20 \%{ }^{13}$

Xanthan gum merupakan bahan pengental untuk meningkatkan viskositas emulsi yang digunakan luas baik secara oral maupun topikal dalam bidang farmasi. ${ }^{13}$ Diketahui xanthan gum banyak digunakan dalam industri makanan karena memiliki sifat kekentalan yang tinggi pada konsentrasi rendah. Xanthan gum umum digunakan bersama dengan gom arab dalam pembuatan emulsi. ${ }^{11}$

Bahan lain yang digunakan yaitu butil hidroksi toluene (BHT). BHT digunakan sebagai antioksidan untuk mencegah oksidasi yang dapat menimbulkan bau tengik dari minyak. Sebagai antioksidan, umumnya BHT digunakan pada konsentrasi $0,01-1 \% .{ }^{13}$ Minyak memiliki rasa dan bau yang tidak enak, oleh karena itu digunakan sakarin dan essence sebagai pemanis dan pengharum. Sakarin adalah zat pemanis yang umum digunakan dalam sediaan oral yang memiliki tingkat kemanisan sekitar 300-600 kali dari sukrosa. Dalam sediaan oral, sakarin dapat digunakan pada konsentrasi $0,02-0,5 \% .{ }^{13}$ Kemudian essence yang digunakan adalah jeruk keprok yang memiliki aroma yang wangi dan tajam untuk menutupi bau minyak ikan lemuru. Kemudian untuk menghindari adanya pertumbuhan mikroba maka digunakan bahan yang berfungsi sebagai antimikroba atau pengawet. Bahan yang digunakan sebagai pengawet adalah natrium benzoat.

Uji organoleptis dilakukan terhadap sediaan emulsi minyak ikan lemuru secara visual yang meliputi warna, bau, rasa, dan homogenitas. Pengamatan ini bertujuan untuk mengetahui perubahan yang mungkin terjadi pada sediaan emulsi setelah dilakukan penyimpanan. Hasil pengamatan organoleptis masing-masing formula sediaan emulsi meliputi bau, warna, rasa dan homogenitas selama masa penyimpanan 30 hari pada suhu $25^{\circ} \mathrm{C}$ dan suhu $40^{\circ} \mathrm{C}$ dapat dilihat pada Tabel 2 dan Tabel 3.

Hasil pengamatan homogenitas pada suhu kamar $25^{\circ} \mathrm{C}$ dan $40^{\circ} \mathrm{C}$ menunjukkan bahwa ketiga formula sediaan emulsi minyak ikan lemuru mengalami pemisahan selama 30 hari penyimpanan. Pemisahan menandakan ketidakstabilan emulsi dimana terjadi penggabungan globul-globul menjadi lebih besar. Ketidaksempurnaan pelapisan globul ini dapat disebabkan antara lain konsentrasi emulgator yang digunakan belum sesuai untuk menyelimuti globul-globul secara optimal atau pengembangan emulgator yang belum sempurna sehingga proses pembentukan lapisan multimolekular belum sempurna. Faktor lain yang mungkin terjadi adalah sistem emulsi yang terbentuk kurang kental, sehingga globul-globul tidak dapat dipertahankan tetap pada posisinya yang mengakibatkan pemisahan semakin membesar. Pemisahan yang lebih cepat terjadi pada suhu $40^{\circ} \mathrm{C}$ juga dapat dikarenakan pengaruh suhu. Peningkatan suhu akan meningkatkan laju 
reaksi, yang berdampak meningkatnya jumlah tumbukan sehingga menaikkan tegangan permukaan. ${ }^{6}$

Ketidakstabilan yang terjadi pada tiap formula juga mempengaruhi bau dan warna selama masa penyimpanan baik pada suhu $25^{\circ} \mathrm{C}$ dan $40^{\circ} \mathrm{C}$. Minyak ikan lemuru memiliki bau minyak yang cukup khas dan berwarna kuning pekat. Akibat dari ketidakstabilan ini bau minyak menjadi lebih tajam serta perubahan warna menjadi lebih kuning dari sebelumnya. Berdasarkan hasil pengamatan organoleptis, diketahui bahwa selama masa penyimpanan pada suhu $25^{\circ} \mathrm{C}$ dan $40^{\circ} \mathrm{C}$, terjadi perubahan bau dan warna ketika sediaan tidak homogen.

Tabel 2. Hasil pengamatan uji organoleptis pada suhu $25^{\circ} \mathrm{C}$

\begin{tabular}{|c|c|c|c|c|c|}
\hline Formula & $\begin{array}{c}\text { Pengamatan } \\
\text { (Hari ke-) }\end{array}$ & Bau & Warna & Rasa & Homogenitas \\
\hline \multirow{5}{*}{$\mathrm{F} 1$} & 0 & Khas & $\begin{array}{c}\text { Putih } \\
\text { kekuningan }\end{array}$ & $\begin{array}{l}\text { Manis sedikit } \\
\text { rasa minyak }\end{array}$ & Homogen \\
\hline & 7 & Khas & $\begin{array}{c}\text { Putih } \\
\text { kekuningan }\end{array}$ & $\begin{array}{l}\text { Manis sedikit } \\
\text { rasa minyak }\end{array}$ & Homogen \\
\hline & 14 & Khas+ & $\begin{array}{l}\text { Kuning } \\
\text { pucat }\end{array}$ & $\begin{array}{l}\text { Lebih terasa } \\
\text { minyak }\end{array}$ & $\begin{array}{l}\text { Pemisahan } \\
\text { fase }\end{array}$ \\
\hline & 21 & Khas++ & $\begin{array}{l}\text { Kuning } \\
\text { pucat }\end{array}$ & $\begin{array}{l}\text { Lebih terasa } \\
\text { minyak }\end{array}$ & $\begin{array}{l}\text { Pemisahan } \\
\text { fase }\end{array}$ \\
\hline & 30 & Khas++ & $\begin{array}{l}\text { Kuning } \\
\text { pucat }\end{array}$ & $\begin{array}{l}\text { Lebih terasa } \\
\text { minyak }\end{array}$ & $\begin{array}{l}\text { Pemisahan } \\
\text { fase }\end{array}$ \\
\hline \multirow{5}{*}{$\mathrm{F} 2$} & 0 & Khas & $\begin{array}{c}\text { Putih } \\
\text { kekuningan }\end{array}$ & $\begin{array}{l}\text { Manis sedikit } \\
\text { rasa minyak }\end{array}$ & Homogen \\
\hline & 7 & Khas & $\begin{array}{c}\text { Putih } \\
\text { kekuningan }\end{array}$ & $\begin{array}{l}\text { Manis sedikit } \\
\text { rasa minyak }\end{array}$ & Homogen \\
\hline & 14 & Khas & $\begin{array}{c}\text { Putih } \\
\text { kekuningan }\end{array}$ & $\begin{array}{l}\text { Manis sedikit } \\
\text { rasa minyak }\end{array}$ & Homogen \\
\hline & 21 & Khas+ & $\begin{array}{l}\text { Kuning } \\
\text { pucat }\end{array}$ & $\begin{array}{l}\text { Lebih terasa } \\
\text { minyak }\end{array}$ & $\begin{array}{l}\text { Pemisahan } \\
\text { Fase }\end{array}$ \\
\hline & 30 & Khas++ & $\begin{array}{l}\text { Kuning } \\
\text { pucat }\end{array}$ & $\begin{array}{l}\text { Lebih terasa } \\
\text { minyak }\end{array}$ & $\begin{array}{l}\text { Pemisahan } \\
\text { Fase }\end{array}$ \\
\hline \multirow{5}{*}{ F3 } & 0 & Khas & $\begin{array}{c}\text { Putih } \\
\text { kekuningan }\end{array}$ & $\begin{array}{l}\text { Manis sedikit } \\
\text { rasa minyak }\end{array}$ & Homogen \\
\hline & 7 & Khas & $\begin{array}{c}\text { Putih } \\
\text { kekuningan }\end{array}$ & $\begin{array}{l}\text { Manis sedikit } \\
\text { rasa minyak }\end{array}$ & Homogen \\
\hline & 14 & Khas & $\begin{array}{l}\text { Putih } \\
\text { kekuningan }\end{array}$ & $\begin{array}{l}\text { Manis sedikit } \\
\text { rasa minyak }\end{array}$ & Homogen \\
\hline & 21 & Khas & $\begin{array}{c}\text { Putih } \\
\text { kekuningan }\end{array}$ & $\begin{array}{l}\text { Manis sedikit } \\
\text { rasa minyak }\end{array}$ & Homogen \\
\hline & 30 & Khas+ & $\begin{array}{l}\text { Kuning } \\
\text { pucat }\end{array}$ & $\begin{array}{l}\text { Lebih terasa } \\
\text { minyak }\end{array}$ & $\begin{array}{l}\text { Pemisahan } \\
\text { Fase }\end{array}$ \\
\hline
\end{tabular}

Uji tipe sediaan emulsi selama masa penyimpanan pada suhu $25^{\circ} \mathrm{C}$ dan suhu $40^{\circ} \mathrm{C}$ dilakukan dengan metode pewarnaan. Metode pewarnaan dipilih karena mudah dan memberikan hasil yang jelas secara visual. Umumnya untuk tipe emulsi minyak dalam air, pewarna yang digunakan untuk pengujian adalah methylene blue karena memiliki sifat hidrofilik sehingga mudah larut dalam air, hasil positif menunjukkan warna akan larut pada emulsi. ${ }^{14}$

Pada metode pewarnaan dengan methylene blue, terlihat warna biru menyebar ke seluruh bagian krim yang dioleskan pada kaca arloji sehingga dapat disimpulkan bahwa tipe sediaan emulsi adalah minyak dalam air. 
Uji tipe emulsi pada masing-masing formula sediaan emulsi dapat dilihat pada Tabel 4 dan Tabel 5.

Uji viskositas dilakukan untuk mengetahui tingkat kekentalan dari sediaan yang dihasilkan. Semakin tinggi viskositasnya maka sediaan tersebut semakin kental. ${ }^{15}$ Hasil pengamatan viskositas dalam $\mathrm{cP}$ (centi poise) dari sediaan emulsi minyak ikan lemuru pada dua suhu $25^{\circ} \mathrm{C}$ dan suhu $40^{\circ} \mathrm{C}$ selama masa penyimpanan dapat dilihat pada Gambar 1 dan Gambar 2.

Tabel 3. Hasil pengamatan uji organoleptis pada suhu $40^{\circ} \mathrm{C}$

\begin{tabular}{|c|c|c|c|c|c|}
\hline Formula & $\begin{array}{c}\text { Pengamatan } \\
\text { (Hari ke-) }\end{array}$ & Bau & Warna & Rasa & Homogenitas \\
\hline \multirow{5}{*}{$\mathrm{F} 1$} & 0 & Khas & $\begin{array}{c}\text { Putih } \\
\text { kekuningan }\end{array}$ & $\begin{array}{l}\text { Manis sedikit } \\
\text { rasa minyak }\end{array}$ & Homogen \\
\hline & 7 & Khas & $\begin{array}{c}\text { Putih } \\
\text { kekuningan }\end{array}$ & $\begin{array}{l}\text { Manis sedikit } \\
\text { rasa minyak }\end{array}$ & Homogen \\
\hline & 14 & Khas+ & $\begin{array}{l}\text { Kuning } \\
\text { pucat }\end{array}$ & $\begin{array}{l}\text { Lebih terasa } \\
\text { minyak }\end{array}$ & $\begin{array}{l}\text { Pemisahan } \\
\text { Fase }\end{array}$ \\
\hline & 21 & Khas++ & $\begin{array}{l}\text { Kuning } \\
\text { pucat }\end{array}$ & $\begin{array}{l}\text { Lebih terasa } \\
\text { minyak }\end{array}$ & $\begin{array}{l}\text { Pemisahan } \\
\text { Fase }\end{array}$ \\
\hline & 30 & Khas++ & $\begin{array}{l}\text { Kuning } \\
\text { pucat }\end{array}$ & $\begin{array}{l}\text { Lebih terasa } \\
\text { minyak }\end{array}$ & $\begin{array}{l}\text { Pemisahan } \\
\text { Fase }\end{array}$ \\
\hline \multirow{5}{*}{$\mathrm{F} 2$} & 0 & Khas & $\begin{array}{c}\text { Putih } \\
\text { kekuningan }\end{array}$ & $\begin{array}{l}\text { Manis sedikit } \\
\text { rasa minyak }\end{array}$ & Homogen \\
\hline & 7 & Khas & $\begin{array}{c}\text { Putih } \\
\text { kekuningan }\end{array}$ & $\begin{array}{l}\text { Manis sedikit } \\
\text { rasa minyak }\end{array}$ & Homogen \\
\hline & 14 & Khas+ & $\begin{array}{l}\text { Kuning } \\
\text { pucat }\end{array}$ & $\begin{array}{l}\text { Lebih terasa } \\
\text { minyak }\end{array}$ & $\begin{array}{l}\text { Pemisahan } \\
\text { Fase }\end{array}$ \\
\hline & 21 & Khas++ & $\begin{array}{l}\text { Kuning } \\
\text { pucat }\end{array}$ & $\begin{array}{l}\text { Lebih terasa } \\
\text { minyak }\end{array}$ & $\begin{array}{l}\text { Pemisahan } \\
\text { Fase }\end{array}$ \\
\hline & 30 & Khas++ & $\begin{array}{l}\text { Kuning } \\
\text { pucat }\end{array}$ & $\begin{array}{l}\text { Lebih terasa } \\
\text { minyak }\end{array}$ & $\begin{array}{l}\text { Pemisahan } \\
\text { Fase }\end{array}$ \\
\hline \multirow{5}{*}{ F3 } & 0 & Khas & $\begin{array}{c}\text { Putih } \\
\text { kekuningan }\end{array}$ & $\begin{array}{l}\text { Manis sedikit } \\
\text { rasa minyak }\end{array}$ & Homogen \\
\hline & 7 & Khas & $\begin{array}{c}\text { Putih } \\
\text { kekuningan }\end{array}$ & $\begin{array}{l}\text { Manis sedikit } \\
\text { rasa minyak }\end{array}$ & Homogen \\
\hline & 14 & Khas & $\begin{array}{c}\text { Putih } \\
\text { kekuningan }\end{array}$ & $\begin{array}{l}\text { Manis sedikit } \\
\text { rasa minyak }\end{array}$ & Homogen \\
\hline & 21 & Khas+ & $\begin{array}{l}\text { Kuning } \\
\text { pucat }\end{array}$ & $\begin{array}{l}\text { Lebih terasa } \\
\text { minyak }\end{array}$ & $\begin{array}{l}\text { Pemisahan } \\
\text { Fase }\end{array}$ \\
\hline & 30 & Khas++ & $\begin{array}{l}\text { Kuning } \\
\text { pucat }\end{array}$ & $\begin{array}{l}\text { Lebih terasa } \\
\text { minyak }\end{array}$ & $\begin{array}{l}\text { Pemisahan } \\
\text { Fase }\end{array}$ \\
\hline
\end{tabular}

Tabel 4. Hasil uji tipe emulsi pada suhu $25^{\circ} \mathrm{C}$

\begin{tabular}{cccc}
\hline \multirow{2}{*}{ Hari ke } & \multicolumn{3}{c}{ Tipe emulsi } \\
\cline { 2 - 4 } & F1 & F2 & F3 \\
\hline 0 & $\mathrm{M} / \mathrm{A}$ & $\mathrm{M} / \mathrm{A}$ & $\mathrm{M} / \mathrm{A}$ \\
7 & $\mathrm{M} / \mathrm{A}$ & $\mathrm{M} / \mathrm{A}$ & $\mathrm{M} / \mathrm{A}$ \\
14 & - & $\mathrm{M} / \mathrm{A}$ & $\mathrm{M} / \mathrm{A}$ \\
21 & - & - & - \\
\hline
\end{tabular}


Tabel 5. Hasil uji tipe emulsi pada suhu $40^{\circ} \mathrm{C}$

\begin{tabular}{cccc}
\hline \multirow{2}{*}{ Hari ke } & \multicolumn{3}{c}{ Tipe emulsi } \\
\cline { 2 - 4 } & F1 & F2 & F3 \\
\hline 0 & $\mathrm{M} / \mathrm{A}$ & $\mathrm{M} / \mathrm{A}$ & $\mathrm{M} / \mathrm{A}$ \\
7 & $\mathrm{M} / \mathrm{A}$ & $\mathrm{M} / \mathrm{A}$ & $\mathrm{M} / \mathrm{A}$ \\
14 & - & - & $\mathrm{M} / \mathrm{A}$ \\
21 & - & - & - \\
30 & - & - & - \\
\hline
\end{tabular}

Pada Gambar 1 dan Gambar 2 dapat dilihat selama masa penyimpanan, hasil pengukuran menujukkan viskositas emulsi F1 lebih rendah dibandingkan dengan $\mathrm{F} 3$. Diantara ketiga formula, F3 dengan konsentrasi minyak sebesar $15 \%$ bersifat paling kental. Perbedaan kekentalan berhubungan dengan meningkatnya jumlah droplet yang terbentuk, semakin banyak jumlah minyak yang ditambahkan maka semakin banyak jumlah droplet yang terbentuk. $^{6}$

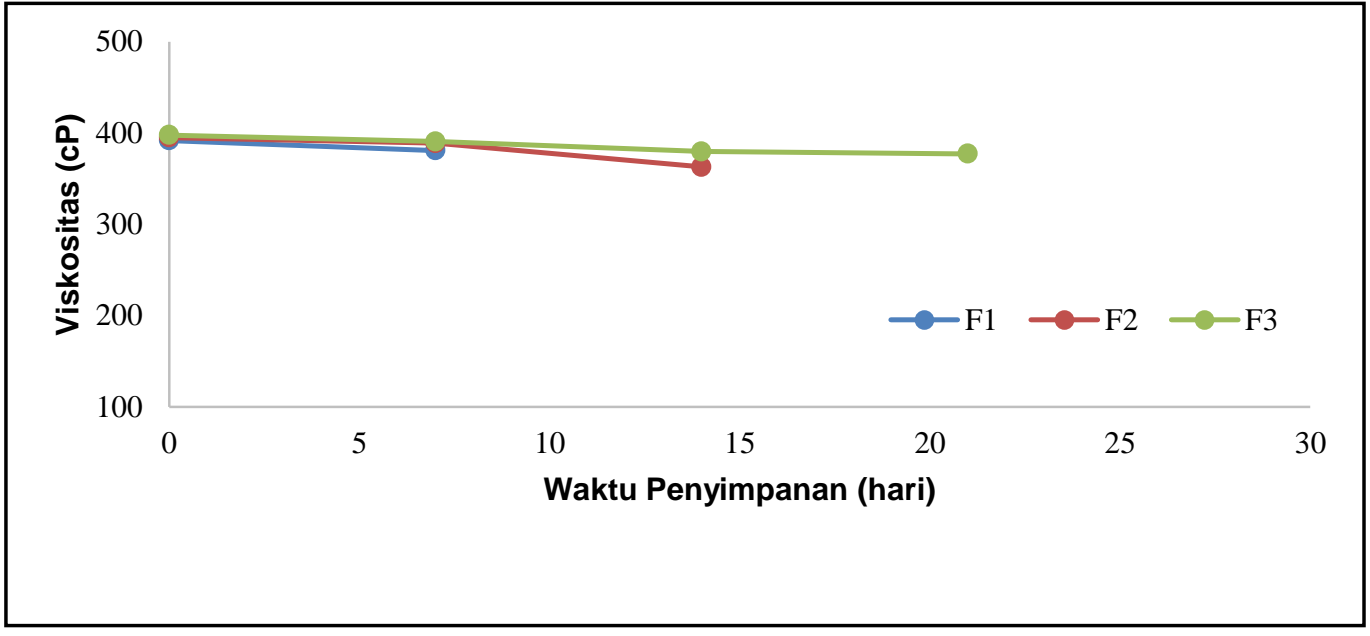

Gambar 1. Hasil pengukuran viskositas emulsi pada suhu $25^{\circ} \mathrm{C}(\mathrm{n}=2)$

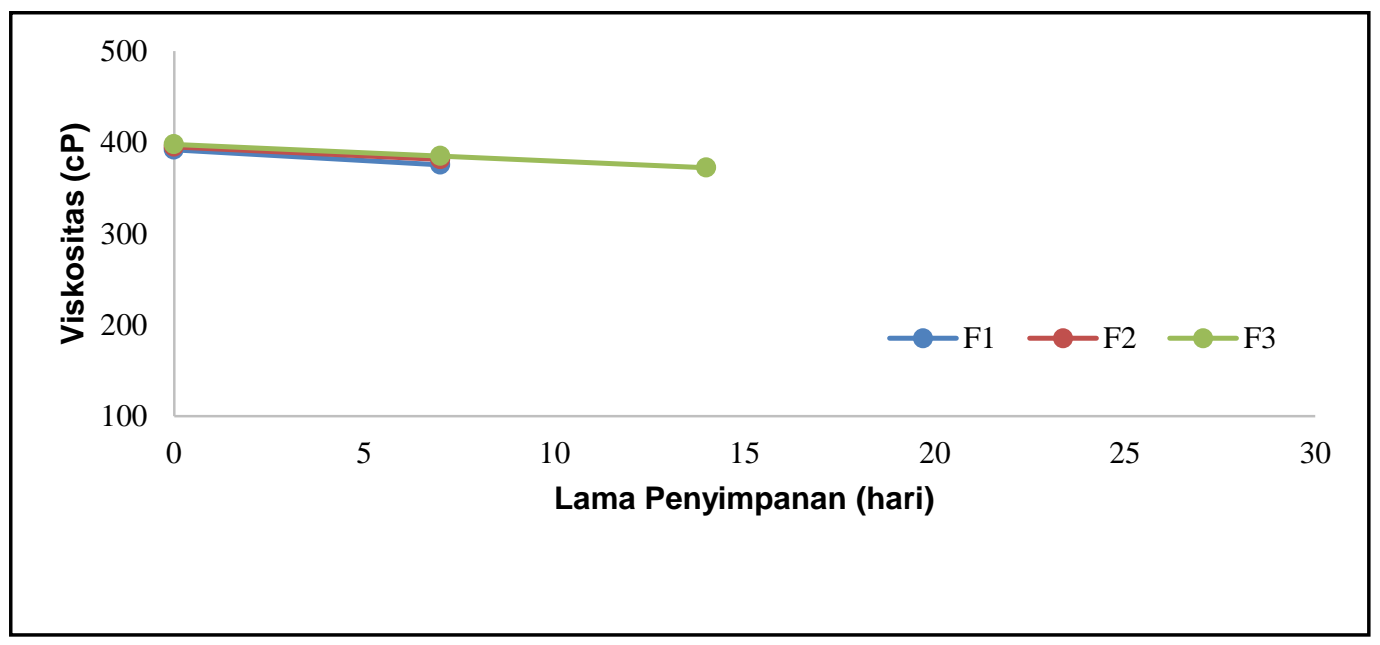

Gambar 2. Hasil pengukuran viskositas emulsi pada suhu $40^{\circ} \mathrm{C}(\mathrm{n}=2)$ 
Tabel 6. Hasil pengukuran diameter globul emulsi minyak ikan lemuru

\begin{tabular}{cc}
\hline Formula & Diameter globul $(\boldsymbol{\mu m})$ \\
\hline F1 & 1,41 \\
F2 & 1,45 \\
F3 & 1,55 \\
\hline
\end{tabular}

Emulsi pada F3 memiliki viskositas yang tinggi dan kestabilan yang paling lama meskipun konsentrasi minyak pada F3 lebih banyak dibandingkan F1 dan F2. Menurut Nikovska $(2012)^{16}$, emulsi dengan viskositas yang lebih tinggi menunjukkan stabilitas emulsi yang lebih baik terhadap pemisahan. Pada konsentrasi minyak yang rendah, viskositas emulsi juga memiliki nilai yang rendah sehingga agregasi droplet dan pembentukan flok akan mengalami peningkatan. Hal ini disebabkan jaringan flokul yang lemah pada emulsi dengan viskositas rendah akan mudah untuk hancur. Sebaliknya, emulsi dengan konsentrasi minyak yang lebih tinggi, tetesan menjadi lebih kompak sehingga terjadi peningkatan viskositas dan interaksi antar droplet, dan dengan demikian menurunkan laju pemisahan. ${ }^{16,17}$

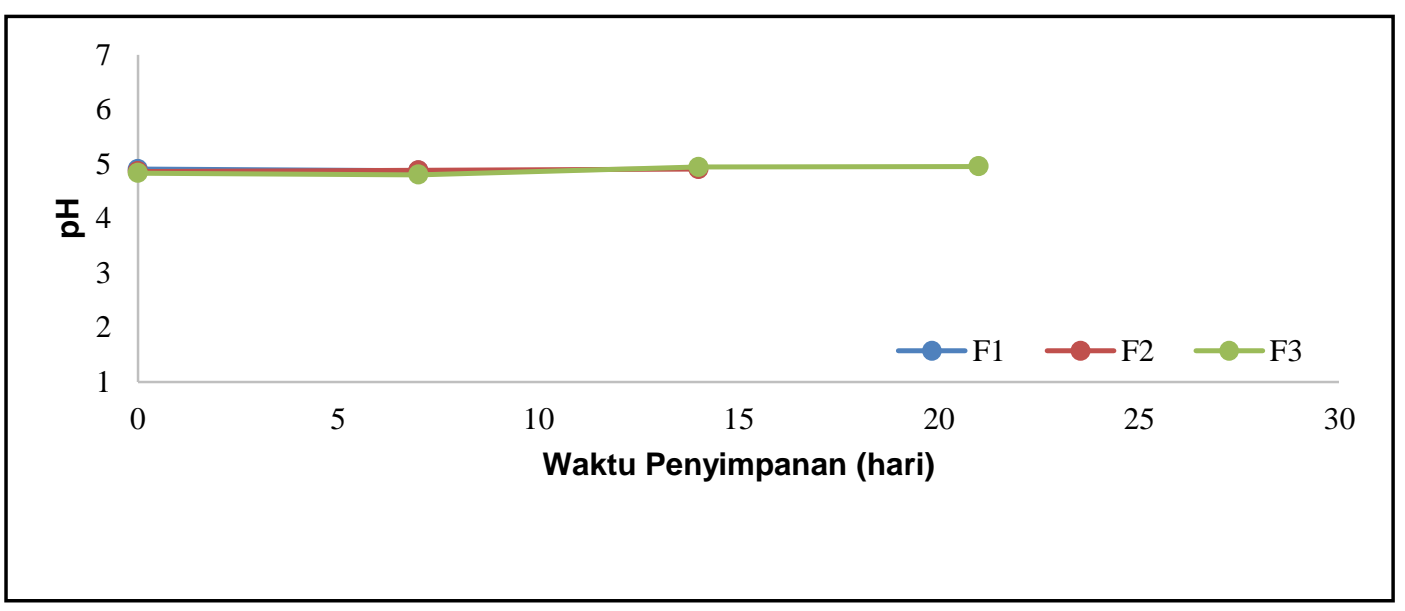

Gambar 3. Hasil pengukuran $\mathrm{pH}$ emulsi pada suhu $25^{\circ} \mathrm{C}(\mathrm{n}=2)$

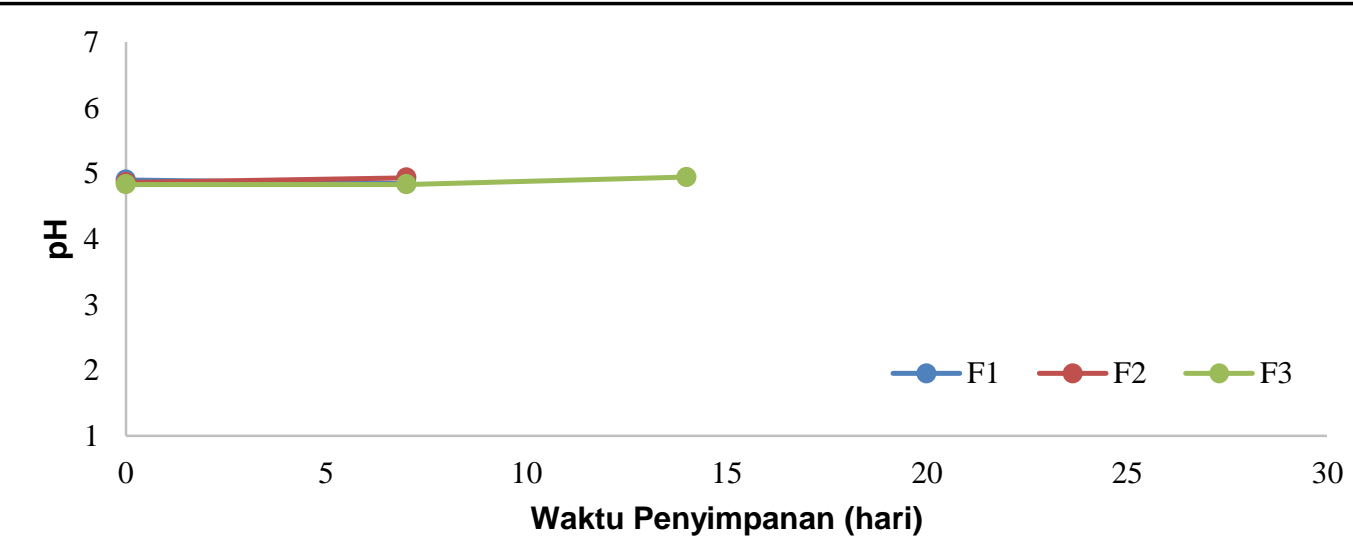

Gambar 4. Hasil pengukuran $\mathrm{pH}$ emulsi pada suhu $40^{\circ} \mathrm{C}(\mathrm{n}=2)$ 
Selama masa penyimpanan, secara keseluruhan viskositas emulsi minyak ikan lemuru mengalami penurunan. Perubahan viskositas emulsi selama masa penyimpanan menunjukkan bahwa telah terjadi perubahan pada emulsi. Penurunan viskositas menunjukkan sediaan semakin encer dimana fase terdispersi akan mudah bergerak dalam fase luar sehingga peluang terjadinya tabrakan antar globul akan semakin tinggi dan mengakibatkan globul-globul cenderung bergabung menjadi partikel yang lebih besar. ${ }^{18}$

Viskositas emulsi yang menurun selama penyimpanan juga dapat disebabkan oleh kenaikan temperatur sehingga menyebabkan viskositas minyak dan emulsifier menurun. Hal ini terjadi selama masa penyimpanan pada suhu $40^{\circ} \mathrm{C}$. Suhu yang tinggi menyebabkan molekul-molekul cairan bergerak dan menyebabkan gaya interaksi antar molekul melemah sehingga menaikkan tegangan permukaan. Peningkatan suhu akan menurunkan viskositas cairan. ${ }^{19}$ Oleh karena itu penyimpanan pada suhu $40^{\circ} \mathrm{C}$ memiliki viskositas yang lebih rendah daripada suhu $25^{\circ} \mathrm{C}$.

Hasil pengukuran $\mathrm{pH}$ dari sediaan emulsi minyak ikan lemuru pada dua kondisi penyimpanan yaitu suhu $25^{\circ} \mathrm{C}$ dan suhu $40^{\circ} \mathrm{C}$ dapat dilihat pada Gambar 3 dan Gambar 4. Berdasarkan data pada Gambar 3 dan Gambar 4 tiap formula memiliki nilai $\mathrm{pH}$ yang tidak jauh berbeda. Pada suhu $25^{\circ} \mathrm{C}$, diperoleh $\mathrm{pH}$ yang berkisar 4,8-4,94 dan pada suhu $40^{\circ} \mathrm{C}$ diperoleh $\mathrm{pH}$ yang berkisar 4,83-4,94. Apabila nilai $\mathrm{pH}$ pada emulsi terlalu rendah, hal ini dapat mempercepat oksidasi lipid sehingga kestabilan emulsi akan mengalami penurunan. Jacobsen $(2004)^{20}$ menyatakan kecepatan oksidasi lipid salah satunya dipengaruhi oleh $\mathrm{pH}$, nilai $\mathrm{pH}$ yang tinggi akan menurunkan kecepatan oksidasi lipid. Oksidasi lipid yang cepat juga dipengaruhi oleh temperatur selama penyimpanan emulsi.

Hasil pengukuran diameter globul rata-rata minyak sediaan emulsi minyak ikan lemuru dapat dilihat pada Tabel 6. Pengukuran dilakukan untuk mengetahui bahwa emulsi yang dibuat masuk ke dalam syarat ukuran globul emulsi. McClements dan $\mathrm{Li} \quad(\text { Tahun })^{10}$ menyatakan ukuran globul sediaan emulsi berada pada rentang 0,1-100 $\mu \mathrm{m}$. Berdasarkan hasil pengukuran globul, ukuran globul yang terbentuk pada emulsi tiap formula masih masuk kedalam kriteria yaitu 0,1-100 $\mu \mathrm{m}$. Ukuran globul emulsi paling kecil ditunjukkan pada emulsi $\mathrm{F} 1$ dan ukuran globul yang paling besar ditunjukkan oleh F3.

\section{KESIMPULAN}

Formula emulsi minyak ikan lemuru yang terbaik selama penelitian dihasilkan pada F3 dengan konsentrasi minyak sebesar 15\%. F3 memiliki kestabilan yang tinggi dibandingkan F1 dan F2 pada dua kondisi suhu. Pengujian stabilitas fisik sediaan emulsi minyak ikan lemuru telah dilakukan dan diperoleh bahwa F3 memiliki kestabilan lebih baik dibandingkan dengan $\mathrm{F} 1$ dan $\mathrm{F} 2$. Kestabilan emulsi F3 bertahan hingga lebih dari 21 hari pada suhu $25^{\circ} \mathrm{C}$ dan lebih dari 14 hari pada suhu $40^{\circ} \mathrm{C}$.

\section{DAFTAR PUSTAKA}

1. Kementerian Kelautan dan Perikanan. Statistika Perikanan Tangkap Indonesia. Jakarta: Direktorat Jenderal Perikanan Tangkap, 2014.

2. Listiyani A, Wiajayanto $D$, Jayanto $B B$. Analysis of CPUE (Catch Per Unit Effort) and Utilization Rates Of Fishery Resource Lemuru (Sardinella lemuru) in the Bali strait. Indonesian Journal of Capture Fish 2017; 1(1):1-9. 
3. Rubio-Rodriguez N, Beltran S, Jaime I. Production of Omega-3 Polyunsaturated Fatty Acid Concentrates. Innovative Food Science \& Emerging Technologies 2010; 11(1):1-12.

4. Haryati K, Suseno H, Nurjanah. Minyak Ikan Sardin Hasil Sentrifugasi dan Adsorben Untuk Emulsi. Jurnal Pengolahan dan Perikanan Indonesia 2017; 20(1):84-94.

5. Permadi A. Kajian Stabilitas Emulsi Minyak Ikan Lemuru (Sardinella lemuru) dan Pengaruhnya Terhadap Efisiensi Enkapsulasi (Thesis). Bogor: Institut Pertanian Bogor, 1999.

6. Suseno $\mathrm{SH}$, Jacoeb $\mathrm{AM}$, Nuryanti $\mathrm{M}$, Ernawati. Sardine (Sardinella sp.) Oil Emulsion and Its Stability During Storage. World Journal of Fish and Marine Sciences 2017; 9(5):31-38.

7. Departemen Kesehatan RI. Farmakope Indonesia. V ed. Jakarta: Departemen Kesehatan, 2014.

8. Hadning I. Formulasi dan Uji Stabilita Fisik Sediaan Oral Emulsi Virgin Coconut Oil. Mutiara Medika 2011; 11(2):88-100.

9. Baliga S, Sangeeta, Muglikar, Rahul K. Salivary $\mathrm{pH}$ : A Diagnostic Biomarker. Journal of Indian Society of Periodontology 2013; 17(4):461-465.

10. McClements DJ, Li Y. Structured Emulsion-Based Delivery Systems: Controlling The Digestion And Release Of Lipophilic Food Components. Advances in Colloid and Interface Science 2010; 159(2):213-228.

11. Desplanques $S$, Frédéric $R$, Michel $G$, Catherine M. Impact of Chemical Composition Of Xanthan And Acacia Gums On The Emulsification And Stability Of Oil-In-Water Emulsions. Food Hydrocolloids 2012; 27:401-410.
12. Dickinson E. Hydrocolloids as Emulsifiers and Emulsion Stabilizers. Food Hydrocolloids 2009; 23:1473-1482.

13. Rowe RC, Sheskey PJ, Quinn ME. Handbook of Pharmaceutical Excipients. 6th ed. London : Pharmaceutical Press, 2009.

14. Kale SN, Sharada LD. Emulsion Micro Emulsion and Nano Emulsion: A Review. Sys Rev Pharm 2017; 8(1):39-47.

15. Fatimah F, Fardiaz D, Apriyantono A, Andarwulan N. Pengaruh Kadar Minyak Terhadap Efektifitas Antioksidan Dalam Sistem Emulsi Oil-In-Water. Jurnal Teknologi dan Industri Pangan 2010; 14(1):39-50.

16. Nikovska K. Study of Olive Oil-In-Water Emulsions With Protein Emulsifiers. J Food Agric 2012; 24(1):17-24.

17. Hadnadev TD, Dokic P, Krstonosic V, Hadnadev M. Influence of Oil Phase Concentration On Droplet Size Distribution and Stability Of Oil-In-Water Emulsions. Eur. J. Lipid Sci. Technol. 2013; 115:313321

18. Traynor MP, Burke R, Frias JM, Gaston E, Barry-Ryan C. Formation and Stability Of An Oil In Water Emulsion Containing Lecithin, Xanthan Gum and Sunflower Oil. International Food Research Journal 2013; 20(5):2173-2181.

19. Seeton CJ. Viscosity-Temperature Correlation for Liquids. Proceedings of IJTC, 2006; 1-12.

20. Timm-Heinrich $M, X u X$, Nielsen NS, Jacobsen C. Oxidative Stability Of Mayonnaise And Milk Drink Produced With Structured Lipids Based On Fish Oil And Caprylic Acid. Eur Food Res Technol 2004; 219:32-41. 